\title{
Why So Few Women Directors in Top UK Boardrooms? Evidence and Theoretical Explanations*
}

\author{
Val Singh** and Susan Vinnicombe
}

Using evidence from a survey of women directors in FTSE 100 companies, this paper considers possible explanations for the persistent homogeneity of top UK boards. Only 61 per cent of the top 100 companies had female directors in 2002, down from 64 per cent in 1999. Women held only 3 per cent of executive (= US inside) directorships, and there were only 15 women executive directors in total. Explanations usually include women's lack of ambition, lack of experience and lack of commitment. These have been disproved by research, but underlying theories of social exclusion may provide insight into this persistent phenomenon.

Keywords: Women, directors, boards, social exclusion, FTSE, UK

\section{Introduction}

$\mathbf{T}$ his paper considers findings from the 2002 UK FTSE 100 study of companies with women directors, and discusses the persistent lack of women on top corporate boards in the light of social exclusion theories. Male directors form an elite group at the top of the UK's corporate world, and few women break through the glass ceiling into this elite, despite making inroads into middle management. The small number of women who rise to director positions in major UK companies is an issue of concern, because women's talents are not being fully utilised.

For the last four years, the number of top UK companies with female directors has been annually monitored. Evidence indicates continuing difficulties for women to reach the very top of major companies in both the UK (Singh et al., 2001) and the USA (Daily et al., 1999). Catalyst has monitored the Fortune 500 regularly since 1996 . The USA had 12.4 per cent female-held seats in the Fortune 500 in 2001, ahead of the UK where there were 6.4 per cent female directors overall in 2001. (The Catalyst census is now biennial.) The FTSE 1002001 survey showed that 39 per cent of top UK companies still had no women on the board, compared to only 13 per cent of Fortune 500 firms. When the situation for executive (= US "inside") directors is examined, in both countries women held only 2 per cent of such directorships on the top corporate boards until 2001.

Evidence shows that senior women do not easily gain access to the boardroom, where an elite group of male directors maintain their power. Zweigenhaft and Domhoff (1998) defined elites as directors and top executives of major corporations, government, civil service and armed forces. In this study, the term "elite" is used to mean those who reach corporate director level, and here specifically the FTSE 100 company boards. The term "gender" is used to mean biological sex, i.e. male or female. Elites are referred to as "upper echelons" of organisations by Hambrick and Mason (1984), and a significant body of research has followed their work into top team diversity, behavioural integration and performance. However, interestingly for this paper on social exclusion, even the most recent top team diversity research has not included
*This paper was presented at the 6th International Conference on Corporate Governance and Board Leadership, 6-8 October 2003 at the Centre for Board Effectiveness, Henley Management College.

**Address for correspondence: Centre for Developing Women Business Leaders, Cranfield School of Management, Cranfield University, Bedford MK43 0AL, UK. Tel: +44 (0)1234-751122; Fax: +44 (0)1234-751806; E-mail: v.singh @cranfield.ac.uk 
"gender diversity" but rather focuses on age, tenure, education and functional background (e.g. Simsek et al., 2002).

This paper briefly reviews the literature on women directors, barriers to the boardroom and tokenism, before describing results of the 2002 Female FTSE 100 Index of companies and women directors. In the discussion section, the figures on women directors are reviewed in light of theoretical perspectives on exclusion (social identity, social networks and social cohesion) which provide interesting explanations for the lack of women in the boardroom, and for the breaking through of the glass ceiling by the successful women who are directors in the UK's top companies.

\section{Barriers for women to reach the top}

Oakley (2000) commented on career barriers hindering women from reaching CEO positions in the USA, which are also very relevant for the UK context and for women trying to achieve elite positions on corporate boards. Organisational barriers include informal and hidden senior promotion processes (AlimoMetcalfe, 1995), lack of appropriate career development (Ragins et al., 1998) and lower pay for women (Oakley, 2000). Behavioural and cultural explanations include gender stereotyping of leadership (Schein and Mueller, 1992); gendered communication styles (Tannen, 1994); management and "fit", corporate culture, power dynamics, old boys' networks and social exclusion (Ragins and Sundstrom, 1989), as well as elements of tokenism (Kanter, 1977). Research reports these barriers not just in the USA but also across Western countries, particularly in maledominated organisations (e.g. Carvalho and Cabral-Cardoso, 2002 in Portugal; Wahl, 1992 in Sweden; Kvande and Rasmussen, 1991 in Norway). Many of these barriers may be unintentional, subtle forms of discrimination.

As their gender is the norm in the business world, most males would experience organisations differently to females, and hence be unaware of what it means to be different. Women's behaviour may be different in organisational life compared to men. Women often eschew the use of impression management, the strategies and tactics which people use to manage their reputation and the perception of their image held by others, especially at work (Singh and Vinnicombe, 2001; Singh et al., 2002). Such strategies include self promotion of ambition and achievements; upwards influencing behaviours such as relationshipbuilding with managers and other key people; and ensuring extra high performance and visible commitment. The effect of such behaviours may directly impact material outcomes. For example, ensuring that one's competence, commitment and ambition are visible to senior managers may result in improved performance ratings as well as attract more resources from above for the team. However, women tend to be more modest than men, they often prefer to share praise rather than take credit due to their personal efforts, and they believe in the fairness of the formal structures (e.g. promotion systems) of the organisation (Rudman, 1998). Hence women do not easily gain upwards visibility and they tend to dislike and avoid organisational politics. Women also prefer experiential learning to formal training (Belenky et al., 1986), which may not be designed to suit their particular learning styles. Women often have different values, choose different paths and don't plan their career portfolios (Vinnicombe and Colwill, 1995). But stereotyping of women's career ambition as less than that of men is a barrier now demonstrated to be untrue. A recent survey of British women managers found that 33 per cent of senior women were aiming to achieve a directorship, even if it meant moving companies (Institute of Management, 2001).

There are differing views between senior women and CEOs regarding the barriers for progress to board positions. In a US survey, Ragins et al. (1998) reported that most CEOs (82 per cent) thought that women were held back by lack of significant general management or line experience, compared to only 47 per cent of the senior women. A massive 64 per cent of CEOs thought that women had not been in the pipeline long enough, compared to only 29 per cent of women. Whilst 52 per cent of the senior women thought male stereotyping held them back, only 25 per cent of the CEOs agreed. Similarly, almost half (49 per cent) of the women said that exclusion from informal networks was a barrier, compared to only 15 per cent of the CEOs.

In the UK, Catalyst and Opportunity Now (2000) reported that a sample of 1188 senior women differed from 117 CEOs regarding views of barriers to women's advancement. The women strongly agreed or agreed on 12 of 16 possible barriers, compared to the CEOs' agreement on only seven items. Stereotyping of women's roles and abilities was seen as a barrier by 81 per cent of senior women but only 65 per cent of CEOs. Only 46 per cent of CEOs but 66 per cent of senior women agreed that exclusion from informal networks was a barrier. Of senior women, 61 per cent felt that personal style differences were a barrier compared to only 26 per cent of CEOs. On organ- 
isational politics, 57 per cent of senior women agreed this was a barrier, but only 35 per cent of CEOs agreed. Sexual harassment was given as a barrier by 40 per cent of senior women but only 27 per cent of CEOs. Importantly, 40 per cent of CEOs agreed that women had not been in the pipeline long enough, compared to only 28 per cent of the women. Of the few females in the CEO sample, 77 per cent reported that stereotyping was the top barrier, compared to 57 per cent of male CEOs. Interestingly, whilst male CEOs recognised the importance of an inhospitable culture as a barrier for women, they did not agree with female CEOs on some of its manifestations, e.g exclusion from informal networks (female CEOs 63 per cent: male CEOs 34 per cent), personal style differences (49 per cent: 11 per cent), and lack of awareness of organisational politics (58 per cent: 19 per cent), all subtle barriers to do with the male-dominated culture.

A study of women and minorities in power elite populations in the US found that women had made substantial progress in the last decade but were not yet in the most powerful positions such as CEOs (Zweigenhaft and Domhoff, 1998). They argued that to achieve top positions, women need to behave and be like the existing members of the elite group. Education and being upper and upper-middle class aided progress.

\section{The business case for gender diversity on boards}

The 2000 FTSE 100 boards study (Singh et al., 2001) reported the business case for more diversity on corporate boards. Better corporate governance should be achieved through the sharing of a broader and different range of experiences and opinions (Fondas and Sassalos, 2000). However, not much has changed since Norburn (1989) wrote that most boards of large UK companies were homogenously constituted, by white, middle class, middleaged males with similar educational and professional backgrounds.

Group work research demonstrates that team diversity can lead to better performance. However, a longer period may be needed at the start for socialisation processes, and if not managed well, diversity can lead to delayed decision-making as well as lower identification with and commitment to the group (Maznevski, 1994). So boards could enhance their team performance by attracting and managing diversity of their membership. Women directors bring a different voice based on their often very different work and non- work experiences to men. They may suggest new ways of bringing products to market, based on knowledge of females as consumers. Daily et al. (1999) state that where companies use market segmentation approaches, women's involvement in corporate strategy is key because of the potential to develop and tailor products to women, for example in the automobile industry where female consumers are a relatively new but increasingly wealthy target group.

Women tend to take the director's role very seriously, which can lead to improved corporate governance through more questioning and open discussion (Fondas and Sassalos, 2000). Women's presence is said to lead to more civilised behaviour and sensitivity to other perspectives, as well as a more interactive and transformational board management style (Rosener, 1990). Companies without women directors may find that large investors such as pension funds start to question whether to put their funds in companies not demonstrating equal opportunities at the top. In addition, women directors play an important part as role models for younger women, and symbolise career possibilities to prospective recruits (Bilimoria, 2000).

\section{Elite populations and tokenism}

Boards of top US and UK companies are remarkably homogenous in terms of gender and ethnic diversity. Whilst there are more companies with women directors in the Fortune 500 than the FTSE 100, of those who do have women directors, most have only one woman in the boardroom. When women are in such a minority at the top of large companies, they are said to be "tokens" (Kanter, 1977). Token theory suggests that when percentages of representation in the community fall below 15 per cent, those who are different are seen as representing their category rather than being seen as individual, because they are so unusual. With a minority of between 15 per cent and 30 per cent, the population is seen as skewed, whilst that between 30 per cent and 40 per cent is seen as tilted. In the skewed population, the minority individuals are less isolated and often provide social support for others. Splits of $60: 40$ are seen as more or less balanced, true balance being reached at 50:50. Token individuals in senior positions have to give attention and make decisions about how to behave in order to fit in the group, using energy that those in the dominant category (males) do not have to expend. Very often, the tokens will seek to be assimilated by having a public face at work, keeping a private face 
hidden. Kanter's view is that when there are two tokens, the isolation is much less.

Tokenism and newly appointed women directors in the FTSE 100 companies were discussed by Bailey (1991), who wrote that "The boardroom is still a male bastion, peopled with what John Betjeman called 'businessmen with awkward hips and dirty jokes upon their lips'". He commented that the enormous press coverage over the appointment of one female executive director showed that this was extremely useful in putting the company in a good light. Another woman director said that she took ages before accepting an invitation to become the only female (non-executive) director of a FTSE 100 board: "There is a danger of tokenism. It's a difficult area for women. There is a good side in that everything you say gets listened to. The bad side is that you are allowed a much lower error rate than men". She also commented on the boardroom culture: "There is a lot of camaraderie, habit and custom when men are together. When you bring a woman in, you indefinably change all that. But after a year or so, it's all forgotten". How much has changed in the ten years since that quote? This paper will present data from 2002 and put the findings into context with some theories of social exclusion.

\section{Methods}

A listing of the FTSE 100 companies was taken from a commercial database in September 2002, which gave information on company size, sector and details of directors. The FTSE 100 is a Financial Times/London Stock Exchange index of the 100 largest listed companies. Companies with female directors were identified, and then company websites were visited for annual reports, biographies of directors and press releases. Company secretaries were faxed to check the findings. The Lexis-Nexis database was checked for further information from newspapers. Data were analysed using SPSS and Excel software. Company demographic variables were examined and means identified, and t-tests used to compare companies with women directors and those with none. In addition, informal interviews were held with two women directors to discuss the findings.

\section{Women directors in top UK companies 2002}

\section{FTSE 100 companies with female directors}

The number of companies with women directors in the UK's top 100 firms, which had gone down from 64 per cent in 1999 to 57 per cent in 2001, increased to 61 per cent in 2002. This slight improvement follows progress being made by women at the top of the UK's public sector (Ross, 2000). In addition, there were 12 companies with female executive (inside) directorships in the whole 100-company index, compared to only eight in 2001, another increase.

When companies were sorted by market capitalisation, 80 per cent of the top 20 FTSE 100 companies had women directors, compared to only 40 per cent of the bottom 20 . This difference is statistically significant $(p=0.007)$. Similar findings have been found in Catalyst studies in the USA (Bilimoria, 2000). Whilst this indicates a relationship between board gender diversity and one measure of financial performance, it does not indicate the direction of the relationship. It could be argued that companies with higher market capitalisation are more open to female director appointments. Bilimoria found that female directors on Fortune 500 boards tended to serve as "additional" seats on boards. This does not seem to be the case in the UK as the top ten boards in the Female Directors Index are only very slightly larger than the average of just under 12 directors.

None of the FTSE 100 companies had more than three female directors, despite the encouraging sign when, for a short period, one company (Legal and General) had four female directors, including one executive director, making 27 per cent of the board.

Marks and Spencer topped the 2002 Index with a 27 per cent female board, including two female executive directors. Making a big jump forward, Sainsbury came in second place with its 25 per cent female board, including a new woman executive director. Also rising fast in the Index was BAA from 27th to 3rd place, with two female executive directors and one nonexecutive. The third place was shared with Astra Zeneca, who were also third in 2001. Whilst still only one company, Pearson, had a female CEO (Marjorie Scardino, an American), the very first female FTSE chairman (Baroness Hogg) was appointed to the board of the venture capital firm 3i Group in 2002.

Six companies had 20-27 per cent female boards, compared to only one in 2000. In addi- 
tion, 28 FTSE 100 firms had 10-19 per cent, and 27 firms had 5-9 per cent female representation on their main boards in 2002. A number of companies who had female directors in 2001 were appointing more women. This is encouraging for women, as it indicates that female directors are holding their own on the previously all-male boards, so much so that the chairmen are open to further female appointments.

As it is sometimes said that older CEOs and chairmen would be resistant to change, and that board size might be important, a check was made to see if there were any significant relationships between the presence of women directors and board size, age of CEO, or age of chairman, but none was identified. The average age of boards was 55 years, of CEOs was 52 years and of chairmen was 61 years. However, there was a very significant relationship between the tenure of the chairmen and the presence of women directors. The longer the chairman's tenure, the less likely there were women on the board. We found that 87 per cent of companies in the bottom of the Female FTSE Index had chairmen with over seven years' tenure.

\section{Female directors (executive and non-executive)}

The percentage of female-held FTSE 100 directorships was 7.2 per cent in 2002, compared to 6.4 per cent in 2001, 5.8 per cent in 2000 and 6.3 per cent in 1999, a slight improvement over the four years. The percentage of female non-executive (= US outside) directors rose from 9.1 per cent in 2000 and 9.6 per cent in 2001 to 10.0 per cent in 2002, but had not yet caught up with the 1999 figure of 10.8 per cent.

The number of female executive (= US inside) directors increased to 15 in 2002 , up from 10 in 2001, and the percentage increased from 2 per cent to 3 per cent. Despite this slight increase, these figures are of particular concern, as they represent opportunities for senior women to progress within their own companies. Only three companies had two female executive directors (Marks and Spencer, BAA and Pearson), and a further nine companies had one female executive. This means that 88 per cent of FTSE 100 companies did not have a female executive director on their main board, and hence did not have role models who could show that in these companies, women could have a career path comparable to that of men. In the "war for talent" in the UK, this may affect corporate reputation as an employer of choice.

\section{Small signs of improvement}

The percentage of women directors overall in 2002 rose to its highest ever level at 7.2 per cent, up from 6.4 per cent in 2001. There was an increase in the number of women holding directorships, and the number of female-held board seats went up from 69 in 2000 to 84 in 2002, higher than ever before. Seventy-five women held 84 directorships in 2002. These are signs of improvement, albeit from a very low baseline.

\section{The right kind of career capital}

Examination of the backgrounds of these top women directors revealed a wealth of talent and experience. Whilst there was still a preponderance of titled women (36 per cent of all women directors), there was an increase in the number of women with PhDs. However, only 21 per cent of male directors held titles, indicating that women may have to prove themselves in order to be in the appointment pool rather more than their male peers, appointed on potential. Catalyst also found that women had to be "branded as successful" before appointment to Fortune 500 directorships.

The average age of the women executive directors was 45 years compared to 52 for males. Average age of women non-executive directors was 55, five years younger than their male peers. Moving forward at a relatively young age seems to be important, perhaps reflecting Rosenbaum's (1989) career tournament model, with pace (progress linked with age) as an indicator of future success.

Interestingly, in 2002, 32 per cent of the women directors were from overseas, of whom at least 13 were American. This is an increase on 2001. An experienced female NED on several boards was asked to comment on this phenomenon of foreign women succeeding in such numbers in the UK, as she had worked in the USA earlier in her career. She felt that the American women were brought up with high expectations from parents and teachers, so that they had less expectation of barriers, a high achievement orientation and high self-confidence, all of which facilitated their career success. These non-British women directors had high-level corporate and often international experience (increasingly seen as a pre-requisite for directorships according to Daily et al., 2000), often entrepreneurial or political talents, and high quality education and had demonstrated ability to succeed in a variety of environments. The women executive directors had significant experience, some 
as technical experts and accountants, others as CEOs of smaller companies and divisional boards. Not surprisingly, the executive directors were in the UK's top female earners list.

\section{Discussion and theoretical explanations}

Whilst these statistics are interesting, particularly as several years of data collection allow trends to be identified, they need to be reviewed in context with the underlying theories around elite groups and social identity and exclusion. The literature review gave an overview of research on the barriers to women's advancement to director level, but the theoretical perspectives allow for further analysis of why these barriers occur and are so persistent.

\section{Social identity theory}

Social identity theory (Tajfel and Turner, 1986; Ashforth and Mael, 1989) allows a deeper understanding of some of the processes involved in this change-resistant phenomenon of female access to major corporate boards. As individuals, we segment and order the social environment around us, defining ourselves and others. Using social categories, we define our membership of various groups, such as family, race, class, location, gender, professions and organisations. Here we are interested in groups based on gender, organisational membership and level. As members of an all-male, almost always allwhite board, male directors will define themselves as directors and as male colleagues and chums, reinforcing group boundaries which exclude non-directors, non-whites and importantly for this study, women, who normally only enter the boardroom as service-providers (as secretaries, tea-ladies and cleaners). Membership of these various groups may vary in importance to the individual at any one time, so that there is a dynamic hierarchy of social identities within the one person and within those who perceive them as potential group members. For example, males seeking directorships will act to behave in a way that demonstrates their suitability for the boardroom, whilst females have to first break that subservient image of women holding little power in a male-dominated enclave, without female role models in the same company.

Because there are so few women at these elite levels, the male directors inevitably have limited experience of senior women as potential equals to themselves. These women do not clearly fall into the categories of females most familiar to the male directors - they are usually different from their wives, their mothers and their secretaries. The males may therefore see a role conflict between gender and work role for potential female directors, and one avoidance strategy is to appoint more males. However, where a strategic gap in the board's competence is identified, the work component of the desired director profile will have more salience than gender. One young female director of marketing said that she had been selected because the board wanted to change the corporate culture to be more customer-oriented, and had identified a gap in the board capability profile. The woman's gender and relative youth would have been less salient to the appointing committee than the technical competence and specific experience in marketing relationships which she had to offer to fill this gap, and hence she was headhunted and appointed as director of the FTSE 100 company.

Within the group, people gain a collective sense of themselves, understanding the norms, building their self-definitions, achieving common goals, trusting and often liking those in the "in-group" and increasing their self-esteem. They start to think in a group way, the so-called "group-think" phenomenon (Maznevski, 1994). They form an exclusive group with its special and privileged knowledge, its own set of rules and a "field" with its own boundaries, a "habitus" (Bourdieu, 1985). As they become in-group members, they tend to stereotype those outside, more often reverting to traditional categories of difference, where gender has high social significance, with women's traditional position as caregiver and nurturer in the private sphere, and less powerful in the external, male-dominated world of business. Kanter (1977) reported that where there were senior females in maledominated organisations, males tended to exaggerate their maleness and sex differences, creating a symbolic barrier that excluded women. Women who emulated that masculine style were then regarded as aggressive and were disliked by both men and other women, leaving them isolated and uncomfortable in that environment.

According to social and organisational identity theory (Tajfel and Turner, 1986; Ashforth and Mael, 1989), group members share their information, and new members in particular tend to compare their own emerging beliefs with similar others. In the interviews, women directors commented that where there was more than one woman on the board, they could exchange views and share information, which helped them settle in as board members. Unless women were included in the 
formal, informal and virtual organisational networks, they would miss out on vital information resources, as they would be outside the community of interaction where knowledge is created, developed and shared (Nonaka, 1994).

Social identity theory holds that there is also a tendency to see performance of similar individuals as higher in the in-group than the out-group. Where gender is the salient characteristic, women will have do that much more to succeed, and men will challenge them just that bit more than they would challenge new males. This may explain why one of the company directors, when asked to confirm the zero statistic regarding women directors on his board, said that they would be delighted to have women on their board, but that there were no women at present who were ready for board positions.

Distinctiveness theory holds that individual demographic attributes such as gender are more salient when they are distinctive within the immediate environmental context, e.g. the all-male corporate board. Hence, gender of prospective directors might be seen as more distinctively different than it really is by the appointing committee or head-hunters. However, a recent consultancy report (Russell Reynolds Associates, 2002) on FTSE 100 chairmen's views of what makes an effective corporate board indicates that the general view was that gender and ethnic minority representation on boards were not important. One CEO said that "diversity was nice to have". The survey covered 68 per cent of FTSE 100 chairmen. The following quotes indicate the depth of the issue for women: "a bit of nationality (mix) is good news, gender and ethnicity do not matter a damn" and "It is important in the perception of the public only".

One chairman said: "It is useful to have a woman NED simply to represent the make-up of our population, but good candidates are hard to find". If we refer to their comments on selection criteria, then it is clear why that view is held. Six out of ten chairmen wanted to select their non-executive directors from those who were CEOs or chairmen of similar sized companies. As there is only one woman CEO, and only one woman chairman of the FTSE 100 companies, it is not surprising that women are in such a minority on these top 100 boards - only two fit the mould! Discussion with a female CEO of a major company outside the FTSE 100 revealed that she had many invitations to become an NED since her very recent appointment as CEO, reinforcing the findings of the Russell study. Yet are these criteria used so strictly for male candidates - there are many male directors in the FTSE 100 index who do not appear to have had CEO status before their appointments as NEDs?

\section{Social networks and social cohesion theory}

The networks of the economic elite are grounded in bureaucratic power, ownership and social capital (Ragins and Sundstrom, 1989; Windolf, 1998). Senior managers represent nodes in these networks with personal and position power, not only in their own organisations but also through links to others in the network, and they benefit not only from these individual features, but also through the aggregated power of the network. Hence patronage is facilitated, as the elite group controls access to the social as well as business network, maintaining the hegemonic power of the dominant elite. On the UK's corporate boards, senior executive directors in one company are very likely to be non-executive directors of another company in the network.

Social cohesion theory can inform the way in which minority individuals such as women are excluded from boards (Westphal and Zajac, 1997). This approach takes a social exchange and reciprocity perspective, where board members are appointed with expectations that they will contribute to third parties within the same broader network, supplying indirect benefits such as information or other appointments. Hence there are multiple actors in this scenario, in this context the non-executive directors, who form a cohesive network of interlocking board memberships. NEDs who are CEOs are most powerful in this arena. It could be argued that women, who are not likely to be CEOs of top firms, based on current statistics, seek access to the board and its networks with less capital to offer than their male peers. Hence they are less attractive to appointing committees. This is then compounded by the fact that supervisors have higher regard for subordinates demographically similar to themselves, and assess their performance as higher than those who are demographically different, even when it is identical (Wayne and Liden, 1995). It is therefore not surprising that so few women get appointed to top boards. Examination of the backgrounds of women who have succeeded indicates that as well as their often outstanding career capital, they bring social capital to the network of directors, by interlocking directorships, by contacts from previous employment, by contacts through voluntary work, and for some titled women as wives of prominent males, by evidence of social relationships within powerful networks. So for women to access these elite positions, they need to show 
that they can contribute beyond the immediate job description to the wider (currently mainly "old boys") network.

\section{Conclusions}

This paper has provided empirical evidence of the position of women directors in the UK's top 100 companies in 2002, contributing to international work in this area (Bilimoria, 2000; Daily et al., 1999). This research shows that despite advances supported by several waves of feminism, and 30 years of equal opportunities and equal pay legislation, there is still clearly a long way to go before women make substantial inroads into UK top boardrooms. Change is very slow, but there are some very small signs of progress. In a number of companies, women are moving ahead, using Kanter's terms, from tokens to minorities. There are 14 companies with 15 per cent or more female representation, where women now have minority rather than token status. There are the beginnings of an identity shift from women directors as elite individuals in relation to women in general to women directors as elite and full members of top corporate boards.

Through several theoretical lenses (social identity, social networks and cohesion theories), potential explanations have been identified for the persistent exclusion of women from top corporate boards. By the very constitution of so many all-male boards (39 per cent of the top 100 companies), the elite male director group does appear to prefer candidates similar to themselves, as social identity theory would predict. The women who have succeeded do bring capital to the social networks by their board positions and interlocking non-executive directorships. The successful women directors have strong backgrounds and significant corporate experience, and do not appear to have been recruited as "token" women.

Whilst it is important to monitor progress regularly of women into top company directorships, further research is needed into the dynamics of board appointments. Qualitative research is needed to understand how gender impacts board selection and performance. Of key importance is the finding in the Russell Reynolds (2002) survey that FTSE 100 chairmen thought gender was not important except as a cosmetic improvement to keep shareholders quiet. These chairmen do not seem to appreciate that women can have something special to contribute to their boards as women, with their different experiences, styles, responsibilities and voice on the board. That diversity might make all the difference to performance in the 21st century. The views of these FTSE 100 chairmen indicate the depth of the barrier which women still have to overcome to reach the elite group of directors at the top of UK companies.

These findings signal an important corporate governance issue, reviewed by the Higgs Review commissioned by the UK government in 2002. Why do 88 of the UK's top 100 companies not have any female executive directors? Why do 39 top companies have no female directors at all? There is a pool of female executive talent for both executive and non-executive appointments, a resource which is not being tapped for its diversity. The issue for chairmen and CEOs is to recognise that there is a strong business case for gender diversity on boards; that these barriers do still exist, and that both real and perceived stereotyping can stop women from achieving their full potential to the benefit of the women and their employers. The questions for chairmen and CEOs to ask are who is responsible, who is accountable and what can be done about it?

The female directors form an elite group of women, who provide role models for younger women - but if women perceive their career paths to be blocked, at wherever the glass ceiling sits in their company, they are increasingly likely to move. As they move to firms where they know that women can achieve those top positions because there are women directors, with them goes the company's investment in recruitment, training and development, the corporate reputation as a womanfriendly employer and, just as important, corporate knowledge. Opening up elite positions in the boardroom to women as well as men would give companies a more balanced profile which should allow them to take advantage of the female talent pool in their own and other companies. That talent pool has been there long enough now - the slow pipeline theory needs to be debunked, with action taken to identify and develop the next generation of female as well as male directors.

\section{References}

Alimo-Metcalfe, B. (1995) Leadership and assessment. In S. M. Vinnicombe and N. L. Colwill (eds) The Essence of Women in Management. Hemel Hempstead: Prentice Hall.

Ashforth, B. E. and Mael, F. (1989) Social Identity Theory and the Organisation, Academy of Management Review, 14, 20-39.

Bailey, E. (1991) Beyond the Glass Ceiling, The Daily Telegraph. London, 21 June.

Belenky, M., Clinchy, B., Goldberger, N. and Tarule, J. (1986) Women's Ways of Knowing. New York: Basic Books. 
Bilimoria, D. (2000) Building the business case for women corporate directors. In R. J. Burke and M. Mattis (eds) Women on Corporate Boards of Directors: International Challenges and Opportunities. Dordrecht: Kluwer Academic.

Bourdieu, P. (1985) The Genesis of the Concepts of 'Habitus' and 'Field' (C. Newman trans.), Sociocriticism, 2, 11-24.

Carvalho, T. and Cabral-Cordoso, C. (2002) Women in Human Resource Management: The Portuguese Case. 2nd EURAM Conference, Stockholm.

Catalyst (1999) 1999 Census of Women Board Directors of the Fortune 1000. New York: Catalyst.

Catalyst and Opportunity Now (2000) Breaking the Barries: Women in Senior Management in the UK, Business in the Community, London.

Daily, C. M., Certo, S. T. and Dalton, D. (1999) A Decade of Corporate Women: Some Progress in the Boardroom, None in the Executive Suite, Strategic Management Journal, 20, 93-99.

Daily, C. M., Certo, S. T. and Dalton, D. (2000) International Experience in the Executive Suite: The Path to Prosperity? Strategic Management Journal, 21, 515-523.

Fondas, N. and Sassalos, S. (2000) A Different Voice in the Boardroom: How the Presence of Women Directors Affects Board Influence over Management, Global Focus, 12, 13-22.

Hambrick, D. C. and Mason, P. A. (1984) Upper Echelons: The Organisation as a Reflection of its Top Managers, Academy of Management Review, 9, 193-206.

Institute of Management (2001) A Woman's Place? London: Institute of Management.

Kanter, R. M. (1977) Men and Women of the Corporation. New York: Basic Books.

Kvande, E. and Rasmussen, B. (1991) Nye Kvinneliv: Kvinner i Menns Organisasjoner. Oslo: Ad Notam Gyldendal.

Maznevski, M. L. (1994) Understanding Our Differences: Performance in Decision-Making Groups with Diverse Members, Human Relations, $47,531-552$.

Nonaka, I. (1994) A Dynamic Theory of Organisational Knowledge Creation, Organization Science, 5, 14-37.

Norburn, D. (1989) The CEO: A Breed Apart, Strategic Management Journal, 10, 1-15.

Oakley, J. G. (2000) Gender-based Barriers to Senior Management Positions: Understanding the Scarcity of Female CEOs, Journal of Business Ethics, 27, 321-334.

Ragins, B. R. and Sundstrom, E. (1989) Gender and Power in Organizations: A Longitudinal Perspective, Psychological Bulletin, 105, 51-88.

Ragins, B. R., Townsend, B. and Mattis, M. (1998) Gender Gap in the Executive Suite: CEOs and Female Executives Report on Breaking the Glass Ceiling, Academy of Management Executive, 12, 28-42.

Rosenbaum, J. E. (1989) ‘Organization career systems and employee misperceptions' in M. B. Arthur, D. T. Hall and B. S. Lawrence (eds.) Handbook of Career Theory Cambridge: Cambridge University Press, pp 437-453.
Rosener, J. B. (1990) Ways Women Lead, Harvard Business Review, Nov/Dec, 119-125.

Ross, K. (2000) Women at the Top 2000: Cracking the Public Sector Glass Ceiling. London: Hansard Society Report.

Rudman, L. A. (1998) Self-promotion as a Risk Factor for Women: The Costs and Benefits of Counter-Stereotypical Impression Management, Journal of Personality and Social Psychology, 74, 629-645.

Russell Reynolds Associates (2002) What Makes an Effective Board? Views from FTSE Chairmen. London: Russell Reynolds Associates.

Schein, V. E. and Mueller, R. (1992) Sex Role Stereotyping and Requisite Management Characteristics: A Cross-Cultural Look, Journal of Organizational Behavior, 13, 439-447.

Simsek, Z., Lubatkin, M. H., Veiga, J. F. and Dino, R. N. (2002) TMT Behavioral Integration, Diversity and Size: Implications for Firm Performance. EGOS Colloquium, Barcelona.

Singh, V. and Vinnicombe, S. (2001) Impression Management, Commitment and Gender: Managing Others' Good Opinions, European Management Journal, 19, 183-194.

Singh, V., Kumra, S. and Vinnicombe, S. (2002) Gender and Impression Management: Playing the Promotion Game, Journal of Business Ethics, 37, 77-89.

Singh, V., Vinnicombe, S. and Johnson, P. (2001) Women Directors on Top UK Boards, Corporate Governance: An International Review, 9, 206-216.

Tajfel, H. and Turner, J. C. (1986) The Social Identity Theory of Intergroup Behavior. In S. Worchel and W. G. Austin (eds) Psychology of Intergroup Relations. Chicago: Nelson-Hall.

Tannen, D. (1994) Talking from 9 to 5: How Women's and Men's Conversational Styles Affect Who gets Ahead, Who Gets Credit and What Gets Done. New York: William Morrow and Co.

Vinnicombe, S. and Colwill, N. L. (1995) The Essence of Women in Management. London: Prentice Hall.

Wahl, A. (1992) Könsstrukturer i Organisationer: Kvinnlige Civilekonomers och Civilingenjörers Karriärutveckling. Stockholm: Ekonomiska Forskningsinstitutet.

Wayne, S. J. and Liden, R. C. (1995) Effects of Impression Management on Performance Ratings: A Longitudinal Study, Academy of Management Journal, 38, 232-260.

Westphal, J. and Zajac, E. J. (1997) Defections from the Inner Circle: Social Exchange, Reciprocity and the Diffusion of Board Independence in US Corporations, Administrative Science Quarterly, 42, 16-39.

Windolf, P. (1998) Elite Networks in Germany and Britain, Sociology, 32, 321-353.

Zweigenhaft, R. and Domhoff, G. W. (1998) Diversity in the Power Elite: Have Women and Minorities Reached the Top. New Haven: Yale University Press.

Val Singh is Senior Research Fellow in Organisational Behaviour at Cranfield School of Management. Research includes the annual 
Female FTSE Index, women and leadership, diversity management, women's networks impression management, commitment, mentoring and role models. She is the Gender Section Editor for the Journal of Business Ethics, has published widely in both academic and practitioner journals (including Long Range Planning, Gender Work \& Organization, Journal of Business Ethics, European Management Journal) and has spoken about her research at many events and international conferences, as well as on radio. She has a particular interest in qualitative research.

Susan Vinnicombe is Director of the Centre for Developing Women Business Leaders, as well as Professor of Organizational Behaviour and Diversity Management. Susan has designed and run award-winning women's management development courses in major organisations. She has written five books, including Working in Organizations, The Essence of Women in Management and Women with Attitude (with John Bank), as well as many journal articles and book chapters, and has appeared on many TV and radio programmes. Susan's research interests are focused on gender diversity in leadership, women directors (the Female FTSE Index), organisational career barriers for women, and executive development.

"We don't want to damage companies. We want them to grow ... We believe that good corporate governance enables them to grow." Brian Baily, Treasurer, West Midlands Pension Funds at the International Corporate Governance Network's Annual Conference 2004, Rio De Janeiro. 